\title{
Thrombospondin in protein malnutrition induced hypoplasia
}

\author{
Trombospondina na hipoplasia induzida \\ por desnutrição protéica
}

Cidônia de Lourdes VITURI ${ }^{1}$

Márcio ALVAREZ-SILVA²

Andréa Gonçalves TRENTIN³

Vera Lúcia Cardoso Garcia TRAMONTE ${ }^{3}$

Primavera BORELLI ${ }^{4}$

\section{A B S T R A C T}

\section{Objective}

The objective of the present study was to measure the concentration of bone marrow extracellular matrix thrombospondin in mice, following hypoplasia induced by protein malnutrition.

\section{Methods}

Two-month-old male Swiss mice were submitted to protein malnutrition by way of a low-protein diet containing $4.0 \%$ casein until they lost $20.0 \%$ of their original body weight, while the control group mice were fed $14.0 \%$ casein for 15 days. The bone marrows of the animals were aspirated and transferred to phosphate-buffered saline tubes for extraction. The extracellular matrix protein was analyzed by $7.5 \%$ SDS-PAGE and thrombospondin by Enhanced Chemiluminescence Light Western blotting.

\section{Results}

The amount of thrombospondin was 30\% higher in the undernourished samples when compared to the control samples.

\section{Conclusion}

This study suggests that the hypoplasia induced by protein malnutrition probably alters the functioning of the bone marrow microenvironment resulting in a higher thrombospondin concentration.

Indexing terms: bone marrow, extracellular matrix, hypoplasia, protein malnutrition, thrombospondin.

\footnotetext{
1 Departamento de Análises Clínicas, Centro de Ciências da Saúde, Universidade Federal de Santa Catarina. Campus Universitário, 88010-970, Florianópolis, SC, Brasil. Correspondência para/Correspondence to: C.L. VITURI. E-mail: <cids@ccs.ufsc.br>.

2 Departamento de Biologia Celular, Embriologia e Genética, Centro de Ciências Biológicas, Universidade Federal de Santa Catarina. Florianópolis, SC, Brasil.

3 Departamento de Nutrição, Centro de Ciências da Saúde, Universidade Federal de Santa Catarina. Florianópolis, SC, Brasil.

4 Departamento de Análises Clínicas e Toxicológicas, Faculdade de Ciências Farmacêuticas, Universidade de São Paulo. São Paulo, SP, Brasil.
} 
728 | C.L. VITURI et al.

\section{RE S U M O}

\section{Objetivo}

O objetivo do presente estudo foi verificar a concentração de trombospondina da matriz extracelular da medula óssea em camundongos após indução de hipoplasia por desnutrição protéica.

\section{Métodos}

Camundongos machos Swiss foram submetidos à desnutrição protéica com uma dieta contendo 4,0\% de caseína até que perdessem 20,0\% do peso original, enquanto o grupo-controle foi mantido com uma dieta contendo 14,0\% de caseína por 15 dias. A medula óssea dos dois grupos foi então aspirada e extraída com tampão fosfato. A matriz extracelular foi analisada por SDS-PAGE 7,5\% e a concentração de trombospondina foi quantificada por Enhanced Chemiluminescence Light Western blotting, com luminescência química avançada.

\section{Resultados}

A quantidade de trombospondina foi 30\% superior nas amostras obtidas de animais desnutridos em relação às amostras do grupo-controle.

\section{Conclusão}

Este estudo sugere que a concentração de trombospondina está aumentada na hipoplasia induzida por desnutrição protéica, provavelmente por alterar o microambiente da medula óssea.

Termos de indexação: medula óssea, matriz extracelular, hipoplasia, desnutrição protéica, trombospondina.

\section{N T RO D U C T IO N}

Thrombospondin (TSP) is a multifunctional glycoprotein of the extracellular matrix (ECM) with a homotrimeric structure of $450 \mathrm{kDa}$. It is made up of identical subunits covalently interlaced in their amino-terminal groupings by disulfide bridges, and contains an RGD sequence at the carboxy-terminal of each subunit. This molecule is synthesized and secreted by a variety of cells, including platelets, fibroblasts, smooth muscle cells and endothelial cells, also being involved in cell adhesion and binding by other components such as glycosaminoglycans and fibrinogen".

TSP is abundant in the microenvironment of the bone marrow, being capable of acting as an adhesive ligand for the development of hematopoietic cells ${ }^{2}$. The production and liberation of blood cells is a function of several factors, and is interfered with in many situations. Protein malnutrition induces a decrease in the production of blood cells, interfering in the processes of phagocytosis, immune response and cell mobilization $^{3}$. Cell mobilization depends on the interaction between blood cells and the ECM of bone marrow. Protein malnutrition induces a particular type of medullary hypoplasia ${ }^{4}$, with architectural modifications that are different from those caused by ordinary hypoplasia and severe medullary aplasia as induced by benzene and its derivatives ${ }^{5}$.

Considering that ECM is essential for the correct functioning of hematopoiesis and that previous studies have shown modifications in the concentrations of laminin and fibronectin in the bone marrow of undernourished animals ${ }^{6}$, this work aimed to evaluate another glycoprotein of great importance in this mechanism, that is, to verify the concentration of thrombospondin in the bone marrow ECM of mice following hypoplasia induced by protein malnutrition.

\section{METHODS}

Male Swiss mice were obtained from the Universidade Federal de Santa Catarina. The two month-old mice were placed in individual metabolic cages. The undernourished group received a diet containing $4 \%$ casein ( $n=23)$, and the control group was fed $14 \%$ casein $(n=19)$ for 15 days, according the AIN-93 protocol ${ }^{7}$. The two groups were maintained under the regular light/dark cycle of 12 hours, with free access to 
diet and water. Their body weight was measured every 48 hours, and the mice were submitted to experimental assays when the undernourished group attained a weight 20\% below their original body weight. The differences between the control and undernourished mice were analyzed by means of the unpaired Student t-test.

The medial portion of the sternum was immediately fixed in Carnoy alcohol and paraffin, and $3 \mu \mathrm{m}$ thick sections produced and stained with Hematoxylin and Eosin.

Bone marrow ECM was obtained from the femurs of the mice. The aspirated marrow was colleted in phosphate-buffered saline $(80 \mathrm{mM}$ $\mathrm{NaH}_{2} \mathrm{PO}_{4}, 20 \mathrm{mM} \mathrm{Na}_{2} \mathrm{HPO}_{4}, 100 \mathrm{mM} \mathrm{NaCl}$, $\mathrm{pH}$ 7.3, containing $2 \mathrm{mM}$ dithiothreitol, $100 \mathrm{mM} 6-$ aminohexanoic acid, $1 \mathrm{mM}$ benzamidine- $\mathrm{HCl}$, and $1 \mathrm{mM}$ phenylmethylsulfonyl fluoride (PMSF). All the reagents were from Sigma Chemical Co., St. Louis, $\mathrm{MO}$, USA, and were maintained at $4^{\circ} \mathrm{C}$ as previously described ${ }^{8}$. The samples were pooled and centrifuged at $2,500 \mathrm{~g}$ for $15 \mathrm{~min}$, and the ECM/ soluble protein-containing supernatant recovered.

The protein was quantified by Bradford's method $^{9}$, using electrophoresis in $7.5 \%$ SDSpolyacrylamide gel (SDS-PAGE) as previously described ${ }^{6}$. The determination of the molecular weight was performed using basis calibration kits (Pharmacia Biotech, SP). The wells were loaded with $45 \mu \mathrm{g}$ of protein obtained from the bone marrow ECM. The electrophoretic transfer of proteins from SDS-PAGE gels to nitrocellulose membranes was performed with a mini V8 system (Gibco BRL). The primary antibodies used were rabbit anti-thrombospondin (a gift from Dra. Veronica Morandi, Universidade Federal do Rio de Janeiro). They were then submitted to the streptavindin-biotin peroxidase method (Sigma, B-7389 and E-2886). Immunodetection was performed by the luminescence method (ECL, Amersham Life Science, UK).

A densitometric analysis was performed using the scanned images from SDS-PAGE gels or with $x$-ray films from Western blot. The images were analyzed and the band areas quantified with the Scion Image program of the National Institutes of Health, and the TSP concentration obtained by densitometric analysis and calculated using the GraphPad Prism program.

\section{RESULTSANDDISCUSSION}

The mice treated with the low-protein diet showed a reduction in body weight (median $=24.1 \pm 6.6 \%$ ), while a small reduction in body weight was observed (median $=4.9 \pm 5.6 \%$ ) in mice treated with the control diet. The differences between the groups were significant $(p<0.0001)$. The undernourished mice developed hypoplasia, presenting a lower than $25.0 \%$ hematopoietic cellularity, with gelatinous degeneration and a widening of the sinusoids (Figures 1 and 2).

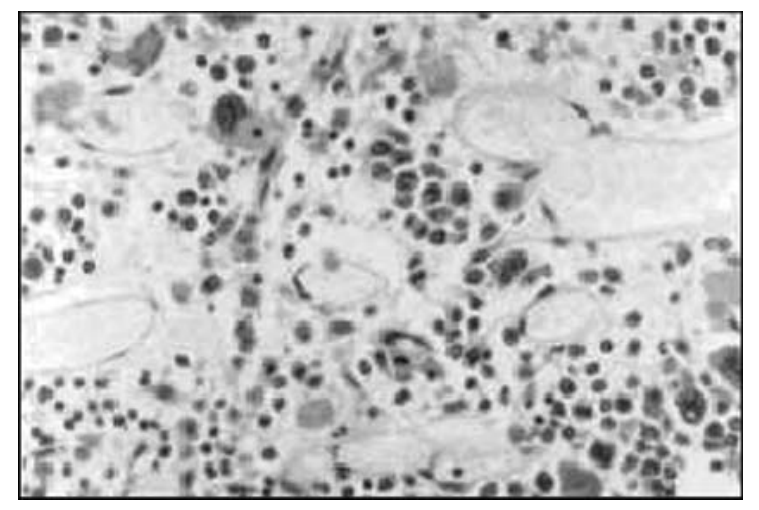

Figure 1. Bone marrow biopsy section from undernourished mice, presenting a lower than $25 \%$ hematopoietic cellularity with gelatinous degeneration and a widening of the sinusoids. Embeded in paraffin, $\mathrm{HE}$ stain $X 400$.

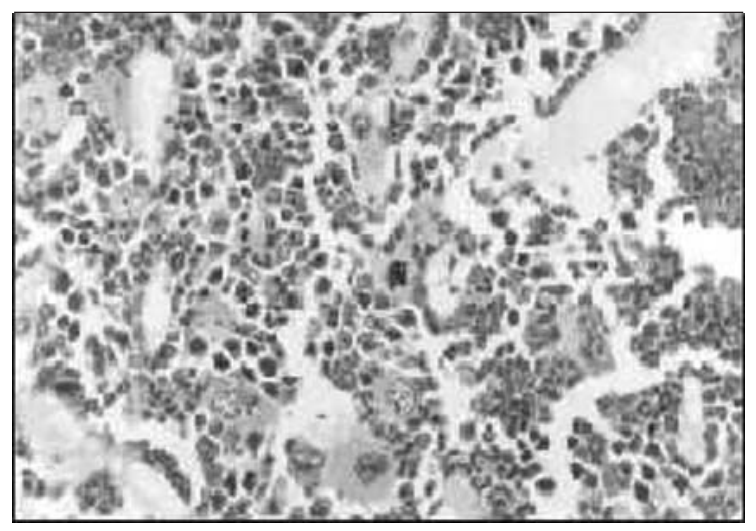

Figure 2. Bone marrow biopsy section from control mice, presenting normal hematopoietic cellularity (over 75\%). Embeded in paraffin, HE stain X 400 . 
Extracellular matrix samples obtained from the femoral bone marrow of undernourished and control mice showed many overlapping protein bands but a few differences were observed in both the control and undernourished groups (Figure 3). The molecular weight of the altered protein corresponded to the TSP subunits (182kDa).

The thrombospondin expression was studied for the control and undernourished samples (Figure 4A), as demonstrated by the densitometric analysis (Figure 4B). The amount of thrombospondin was 30\% higher in the undernourished sample when compared to the control sample. Different groups of control and undernourished mice were tested, with similar results.

Using a protein malnutrition model ${ }^{8}$ alterations in the protein content of the bone marrow ECM were demonstrated, suggesting alterations in the hematopoietic microenvironment. In this respect Vituri et al. observed quantitative alterations in the concentrations of laminin and fibronectin in the bone marrow ECM of undernourished mice.

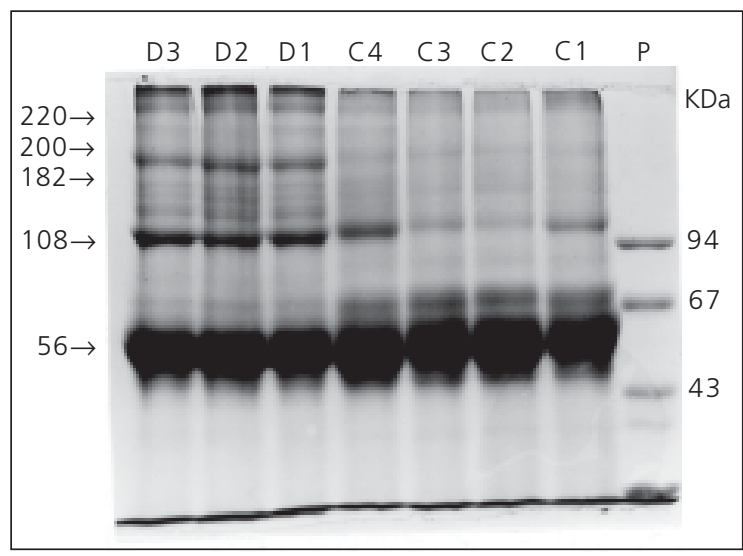

Figure 3. SDS-PAGE profile of ECM proteins obtained from control and undernourished mice. Lane $\mathbf{D}$ refers to samples obtained from the undernourished mice group. Lane $\mathbf{C}$ refers to samples obtained from the control group. Differences were observed in the intensity of the proteins with molecular weights of 240, 182 and 108kDa in both the groups analyzed. Different groups of control and undernourished mice were tested, with similar results.

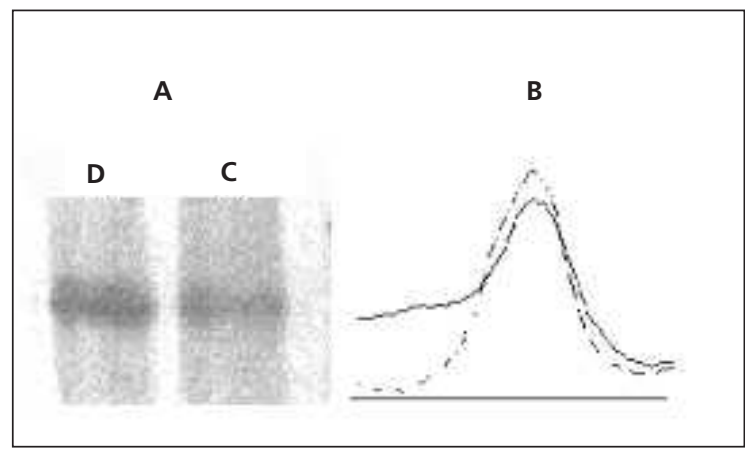

Figure 4. Western blot reaction against extracellular matrix protein thrombospondin (TSP). These data were obtained from SDS-PAGE blotted against thrombospondin (A). Lane D refers to samples obtained from the undernourished group. Lane $\mathbf{C}$ refers to samples obtained from the control group. Densitometric analysis of thrombospondin bands (B). Solid line refers to control samples. Dashed line refers to undernourished samples.

TSP is a large multifunctional protein that regulates cell adhesion, angiogenesis, cell proliferation and survival, transforming growth factor (TGF) beta activation and protease function ${ }^{10}$. The results of this study suggest that protein malnutrition may be the cause of architectural alterations in the bone marrow as well as a higher expression of thrombospondin in undernourished mice. Since TSP is involved in angiogenesis, this may explain the modifications found in the medullary sinusoids (Figure 1). The production of blood cells in a constant pattern depends on the microenvironment components existing in the medullary cavity. The sequence of events is not quite clear: one hypothesis is that the initial event may be related to the hematopoietic stem cell or with some of its progenitors, and that the hypoplasia may cause a particular kind of architectural lesion, introducing alterations in cell proliferation of the medullary stroma or modifications in the ECM molecule synthesis. However, other deviations may be involved in the metabolic mechanisms. The matrix composition is not static; it is modified during normal development and under conditions of tissue repair and regeneration ${ }^{11,12}$. The remodeling process may act by splicing growth factors sequestered by ECM, and also through cell surface 
receptors important in cell signaling ${ }^{13}$. Discreet alterations in the ECM structure may then occur, resulting in significant alterations in cell behavior.

It has recently been demonstrated that variations in TSP concentration may modify proteoglycan metabolism, the stoichiometry being critical in the maintenance of the ECM molecules ${ }^{14}$. The present study showed that protein malnutrition-induced-hypoplasia modified the TSP concentration in the bone marrow of mice. Previous studies showed that protein malnutrition induced a delay in the migration of defense cells to an inflammatory focus ${ }^{3}$. Therefore, it is suggested that these quantitative alterations in ECM also modify the functioning of the marrow microenvironment, altering cell proliferation and the release of haematopoietic cells into circulation. In conclusion, it is proposed that the expression of TSP is modified in hypoplasia due to protein malnutrition and that architectural modifications of the medullary sinusoids may be related to the higher concentration of TSP in the bone marrow. Nonetheless, the in vitro biological effects of bone marrow ECM obtained from undernourished animals deserve further investigation.

\section{ACKNOWLEDGEMENTS}

Supported in part by FUNPESQUISA/2002, UFSC and FAPESP 97/13347-4. We thank Prof Dr. José Guilherme Xavier for his help in the histopathological assays.

\section{REFERE NCES}

1. Bornstein P. Thrombospondins: structure and regulation of expression. FASEB J. 1992; 6(14):3290-9.

2. Klein G. The extracellular matrix of the hematopoietic microenvironment. Experientia. 1995; 51(9-10):914-26.
3. Borelli P, Mariano M, Borojevic R. Protein malnutrition: effect on myeloid cell production and mobilization into inflammatory reactions in mice. Nutr Res. 1995; 15(10):1477-85.

4. Krause JR. The bone marrow in nutritional deficiencies. Hematol Oncol Clin North Am. 1988; 2(4):557-67.

5. Yong NS, Alter BP. Drugs and chemicals. In: Young NS, Alter BP. Aplastic acquired and inherited. Philadelphia: WB Saunders; 1994. p.24-31.

6. Vituri $C L$, Alvarez-Silva $M$, Trentin AG, Borelli P. Alterations in proteins of bone marrow extracellular matrix in undernourished mice. Braz J Med Biol Res. 2000; 33(8):889-95.

7. Reeves PG, Nielsen FH, Fahey GC. AIN-93 purified diets for laboratory rodents: final report of the American Institute of Nutrition Ad Doc committee on the reformulation of the AIN-76A rodent diet. J Nutr. 1993; 123(5):1939-51.

8. Bradford MM. A rapid and sensitive method for the quantitation of microgram quantities of protein utilizing the principle of protein-dye binding. Anal Biochem. 1976; 72(1-2):248-54.

9. Vituri $\mathrm{CL}$, Alvarez-Silva $\mathrm{M}$, Borelli P. Desnutrição protéica altera o microambiente hematopoiético. Rev Bras Cienc Farm.1999; 35(1):8.

10. Silverstein RL. The face of TSP revealed: an extracellular signaling domain is exposed. J Cell Biol. 2002; 159(2):203-6

11. Yurchenco PD, O'Rear JJ. Basal lamina assembly. Curr Opin Cell Biol. 1994; 6(5):674-81.

12. Sottile J, Hocking DC. Fibronectin polymerization regulates the composition and stability of extracellular matrix fibrils and cell-matrix adhesions. Mol Biol Cell. 2002; 13(10):3546-59.

13. Streuli C. Extracellular matrix remodeling and cellular differentiation. Curr Opin Cell Biol. 1999; 11(5):634-40

14. Grzesik WJ, Frazier CR, Shapiro JR, Sponseller PD, Robey PG, Fedarko NS. Age-related changes in human bone proteoglycan structure. Impact of osteogenesis imperfecta. J Biol Chem. 2002; 277(46):43638-47.

Received for publication on July 16th 2004 and accepted on April 12th 2005 